\title{
MODEL JARINGAN SYARAF TIRUAN UNTUK MEMPREDIKSI KADAR AIR BAHAN PADA PNEUMATIC CONVEYING RECIRCULATED DRYER
}

\section{ARTIFICIAL NEURAL NETWORKS MODEL FOR PREDICTION OF MOISTURE CONTENT OF THE MATERIAL ON PNEUMATIC CONVEYING RECIRCULATED DRYER}

\author{
Abadi Jading ${ }^{1 *}$, Nursigit Bintoro' ${ }^{2)}$, Lilik Sutiarso' ${ }^{2)}$, Joko Nugroho Wahyu Karyadi ${ }^{2}$ \\ ${ }^{1)}$ Jurusan Teknologi Pertanian, Fakultas Teknologi Pertanian, Universitas Papua, \\ Jl. Gunung Salju, Amban, Manokwari, Papua Barat 98314, Indonesia \\ Email: a_jading@yahoo.com; abajading@gmail.com \\ ${ }^{2)}$ Departemen Teknik Pertanian dan Biosistem, Fakultas Teknologi Pertanian, Universitas Gadjah Mada, \\ J1. Flora No. 1, Bulaksumur, Yogyakarta 55281, Indonesia
}

Makalah: Diterima 22 November 2016; Diperbaiki 19 Juni 2017; Disetujui 28 Juni 2017

\begin{abstract}
Recirculation drying process ofmaterial on pneumatic conveying recirculated dryer (PCRD) are very complexand not linear, so it is very difficult to predict the final required moisture content.The purpose of this study was to develop a model of Artificial Neural Networks (ANN) to predict the final moisture content of the material on the PCRD machine. In this study, PCRD machine has been designed with variability in recirculation, and ANN Graphical User Interface (GUI) application using Neural Network in computer software. AAN models have been designed using the structure of a network with 11 input neurons, hidden multilayers neurons, and one output neuron with backpropagation learning algorithm. Training and testing of models using 54 and 27 data set observations respectively. The validity test results of the model obtained the value of $r^{2}$ trainning was 0.99 or $99 \%$, and $r^{2}$ of the testingwas 0.96 or $96 \%$. This indicated that the models are very valid to predict the final moisture content of the materialon the PCRD machine. The results also revealed RMSE, MAE, MRE value of ANN optimization model was $0.118 \% \mathrm{wb}, 0.056 \% \mathrm{wb}$, and $0.644 \%$ respectively. While the value of RMSE, MAE, MRE ofthe process of the model testing was $0.226 \% \mathrm{wb}, 0.129 \% \mathrm{wb}$, and $1.496 \%$ respectively.
\end{abstract}

Keywords: prediction, moisture content, models, pneumatic recirculated conveying dryer, artificial neural network

\section{ABSTRAK}

Proses pengeringan bahan secara resirkulasi pada pneumatic conveying recirculated dryer (PCRD) sangat rumit dan tidak linier, sehingga sulit untuk memprediksi kadar air akhir bahan sesuai dengan yang disyaratkan. Tujuan penelitian ini adalah mengembangkan model jaringan syaraf tiruan (JST) untuk memprediksi kadar air akhir bahan pada mesin PCRD. Pada penelitian ini telah dirancang mesin PCRD dengan variasi variabel secara resirkulasi dan aplikasi Graphical User Interface (GUI) JST menggunakan software Neural Network Toolbox pada software komputer. Model JST dirancang menggunakan struktur jaringan yang terdiri dari 11 neuron input, hidden multilayer, dan satu neuron output dengan algoritma pembelajaran backpropagation. Pelatihan dan pengujian model menggunakan data observasi masing-masing sebanyak 54 dan 27 set data. Uji validitas model memperoleh nilai $\mathrm{r}^{2}$ latih sebesar 0,99 atau $99 \%$, dan $\mathrm{r}^{2}$ uji sebesar 0,96 atau $96 \%$. Hal ini menunjukkan bahwa model sangat valid digunakan untuk memprediksi kadar air akhir bahan pada mesin PCRD. Optimasi model JST pada proses pelatihan mempunyai nilai RMSE sebesar 0,118\% wb, MAE 0,056\% wb dan MRE 0,644\%. Nilai optimasi model JST pada proses pengujian adalah RMSE sebesar 0,226\% wb, MAE $0,129 \%$ wb dan MRE $1,496 \%$.

Kata kunci: prediksi, kadar air, model, pneumatic conveying recirculated dryer, jaringan syaraf tiruan

\section{PENDAHULUAN}

Pneumatic conveying recirculated dryer (PCRD) adalah pengembangan dari pneumatic conveying dryer (PCD) atau flash dryer dan umumnya digunakan pada industri pengeringan bahan-bahan tepung. Mesin PCRD pada umumnya dilengkapi unit penggilingan (milling) dan resirkulasi bahan (manifold). Waktu tinggal bahan pada mesin PCRD adalah 30-300 detik (Cristiansen dan Sardo, 2001; Frosterud et al., 2011). Pada penelitian ini telah dikembangkan mesin PCRD dengan merancang manifold berbentuk siklon resirkulasi yang dilengkapi blower sentrifugal untuk meresirkulasi dan memisahkan bahan basah dengan kering. Siklon resirkulasi bahan tersebut, dihubungkan secara seri dengan siklon output bahan. Pemisahan bahan basah dan kering pada siklon resirkulasi sangat menentukan tingkat kadar air akhir bahan yang dihasilkan selama proses pengeringan. Kadar air akhir bahan adalah salah satu parameter untuk menentukan keberhasilan proses pengeringan. 
Proses pengeringan bahan pada mesin PCRD berlangsung secara cepat, sehingga sulit untuk mengukur perubahan kadar air akhir bahan secara langsung atau real time. Selain itu, belum tersedianya alat ukur kadar air bahan secara real time yang digunakan untuk mengukur kadar air akhir bahan pada mesin PCRD. Pengukuran kadar air akhir bahan dilakukan secara tidak langsung dengan metode oven atau gravimetri. Oleh karena itu, diperlukan model untuk memprediksi kadar air akhir bahan pada mesin PCRD.

Untuk memprediksi perubahan kadar air bahan selama proses pengeringan secara resirkulasi pada mesin PCRD, maka diperlukan model hubungan variabel-variabel pengeringan yang berpengaruh terhadap perubahan kadar air akhir bahan. Namun demikian, proses resirkulasi bahan pada mesin PCRD sangat rumit, dan tidak linier sehingga pada penelitian ini, dikembangkan model jaringan syaraf tiruan (JST) untuk memprediksi kadar air akhir bahan pada mesin PCRD.

Jaringan syaraf tiruan (JST) atau artificial neural network (ANN) adalah sistem komputasi dengan arsitektur dan operasi berdasarkan pengetahuan tentang sel syaraf biologis dalam otak, yang merupakan salah satu representasi buatan dari otak manusia. JST dapat digambarkan sebagai model matematis dan komputasi untuk fungsi aproksimasi non-linier, klasifikasi data cluster, dan regresi nonparametrik atau sebuah simulasi dari koleksi model syaraf biologi. Selain itu, JST mampu menangani sistem yang kompleks, rumit, dan tidak linier, serta mampu belajar dengan variabel-variabel keputusan (decision variabels), seperti halnya pada proses pengeringan. JST sangat baik digunakan untuk pemodelan dinamikkarena tidak membutuhkan parameter-parameter model fisik dan mampu belajar dari data eksperimen (Mittal dan Zhang, 2001; Siang, 2005; Hermawan, 2006; Boeri et al., 2011).

JST telah banyak digunakan untuk memprediksi kadar air bahan terhadap beberapa variabel pada proses pengeringan, namun demikian belum ada model sejenisuntuk memprediksi kadar air bahan, yang dihubungkan dengan variabel proses pengeringan resirkulasi secara kontinyu pada mesin PCRD. Model-model JST yang telah dibangunyang menghubungkanvariabel proses pengeringan dengan kadar air akhir telah banyak dilakukan. Beberapa penelitaian tersebut adalah Satish dan Setty (2005) untuk pemodelan pengering fluidized bed secara kontinyu menggunakan JST, Torrecilla et al. (2005) melakukan pemodelan pengeringan alpurejo dengan JST. Lertworasirikul dan Tipsuwan (2007) memprediksi kadar air dan aktivitas air semi-finished cassava crackers menggunakan JST. Shrivastav dan Kumbhar (2009) melakukan pemodelan dan optimisasi untuk memprediksi kadar air, laju pengeringan dan moisture ratio pada low pressure superheated steam dryer dengan JST. Topuz (2010) memprediksi kadar air produk pertanian dengan JST.
Boeri et al. (2011) mengembangkan JST untuk memprediksi kadar air pada pengeringan codfish. Kassem et al. (2011) memprediksi efisiensi pengeringan buah anggur pada box dryer menggunakan JST. Singh dan Pandey (2011) menggunakan pendekatan JST untuk memprediksi kinetika pengeringan pada pengeringan ubi jalar. Motevali et al. (2013) menggunakan JST untuk menentukan energi aktivasi dan difusivitas lengas efektif dill leaves. Kaveh dan Chayyan (2014) memprediksi beberapa sifat fisik dan pengeringan terebinthfruit menggunakan JST. Chayjan et al. (2014) memodelkan beberapa karakteristik pengeringan sour cherry pada pengering inframerah menggunakan model JST.

Tujuan penelitian ini adalah mengembangkan model JST untuk memprediksi kadar air akhir bahan pada mesin PCRD.

\section{BAHAN DAN METODE}

\section{Bahan dan Alat}

Bahan yang digunakan pada penelitian ini adalah pati sagu basah yang diperoleh dari daerah Tulung, Klaten, Jawa Tengah. Bahan dikeringkan menggunakan mesin PCRD untuk memperoleh data kadar air akhir bahan yang digunakan sebagai output pada pelatihan dan pengujian model JST. Mesin PCRD yang digunakan pada penelitian ini adalah hasil rancangan dan pengembangan pada penelitian pendahuluan. Skema mesin PCRD dapat dilihat pada Gambar 1, terdiri dari delapan komponen (unit) utama yaitu (1) tungku pemanas berbahan bakar LPG, (2) Blowersentrifugal sebagai disintegrator dengan penggerak motor listrik 3 phasa, $380 \mathrm{~V}, 2 \mathrm{hp}$, (2) Pengumpan input bahan (silinder bergigi dengan penggerak motor listrik 1 phasa, 220V, $1 \mathrm{hp}$ ), (3) Pipa pengering berbentuk recirculated (vertikal dan horizontal), (4) Manifold atau siklon resirkulasi dan pemisah bahan, (5) blowersentrifugal dengan penggerak motor listrik 1 phasa, 220V, $1 \mathrm{hp}$ ), (6) Siklon output bahan, (7) penampung bahan kering dan (8) panel kontrol.

Prosedur pengoperasian mesin PCRD, yaitu bahan pati sagu basah dimasukkan pada pengumpan, kemudian menyalakan tungku berbahan bakar LPG dan menjalankan blower sentrifugal disintegrator dan blower sentrifugal manifold. Bahan yang masuk pada pengumpan terangkut oleh udara panas melalui pipa resirkulasi. Bahan basah dan kering akan terpisah secara otomatis dan kontinyu pada unit manifold atau siklon resirkulasi bahan. Bahan kering keluar menuju siklon output dan ditampung pada tempat penampungan bahan kering. Bahan basah tersirkulasi kembali sampai kering. Alat bantu lainnya yang digunakan pada penelitian ini antara lain, pengempa hidrolik manual WESTICO (1000 bar). thermometer 4 channel LUTRON TM-946, termokopel tipe K $\left(-199,9-1370^{\circ} \mathrm{C}\right)$. Hygrometer meter digital merek KRISBOW KW06-291, air flow 
meter merek KRISBOW, Tacho meter LUTRON DT-1236L laser contact, timbangan digital tiga digit OHAUS (maksimum $200 \mathrm{~g}$ ), dan oven listrik MEMMERT.

Aplikasi yang digunakan untuk menganalisis model adalah simulator Graphical User Interface (GUI) JST berbasis Neural Network Toolbox MATLAB Versi 2014a. Aplikasi GUIJST tersebut, adalah hasil rancangan dan pengembangan yang dilakukan pada penelitian pendahuluan. Aplikasi GUI JST berbasis Neural Network Toolbox computer software telah terpasang dalam seperangkat laptop dengan CPU Intel Core i34030u, 1,9 GHz, memori $4 \mathrm{~GB}$, dan hard disk 500 GB.

\section{Metode}

Tahapan pengembangan model JST meliputi pengumpulan dan pemisahan data observasi (kadar air awal dan akhir bahan). Selanjutnya adalah menentukan struktur jaringan, memilih algoritma pembelajaran, menginisialisasi parameter jaringan. Tahapan akhir adalah Input data pelatihan dan pengujian, pelatihan, pengujian, dan implementasi JST (Hermawan, 2006).

\section{Prosedur Pengambilan Data Observasi}

Data yang digunakan sebagai input layer dan output layer pelatihan dan pengujian model JST pada penelitian ini, adalah data observasi yang diperoleh dari nilai perlakuan variabel variasi, dan kadar air akhir bahan pada mesin PCRD. Variabel variasi proses pengeringan resirkulasi secara kontinyu, yang digunakan pada mesin PCRD sebanyak 9 variabel. Variabel variasi tersebut adalah kadar air awal bahan $\left(\mathrm{M}_{\mathrm{ib}}\right)$, kecepatan udara pengering $\left(\mathrm{v}_{\mathrm{u}}\right)$, dan suhu udara pengering $\left(\mathrm{T}_{\mathrm{u} 3}\right)$. Variabel variasi selanjutnya adalah panjang pipa resirkulasi $\left(\mathrm{L}_{\mathrm{p}}\right)$, tinggi silinder siklon resirkulasi $\left(\mathrm{L}_{\mathrm{scrb}}\right)$, diameter $\left(\mathrm{D}_{\text {Acrb }}\right)$ dan panjang $\left(\mathrm{L}_{\mathrm{Acrb}}\right)$ pipa outlet atas pada siklon resirkulasi. Variabel variasi berikutnya adalah kecepatan udara blower pada siklon resirkulasi ( $\left.\mathrm{V}_{\mathrm{ucrb}}\right)$, dan kapasitas input bahan $\left(Q_{i b}\right)$. Variabel konstan yang digunakan adalah suhu lingkungan $\left(\mathrm{T}_{\text {ling }}\right)$ dan kelembaban udara relatif (R $\mathrm{R}_{\text {Hling }}$ ). Variabel $\mathrm{M}_{\mathrm{ib}}, \mathrm{v}_{\mathrm{u}}, \mathrm{T}_{\mathrm{u} 3}, \mathrm{~L}_{\mathrm{p}}, \mathrm{L}_{\mathrm{scrb}}, \mathrm{D}_{\text {Acrb }}, \mathrm{L}_{\mathrm{Acrb}}$, $\mathrm{V}_{\mathrm{ucrb}}, \mathrm{Q}_{\mathrm{ib}}, \mathrm{T}_{\text {ling }}$ dan $\mathrm{R}_{\text {ling }}$ digunakan sebagai variabel input layer pada model JST. Variabel kadar air akhir bahan $\left(\mathrm{M}_{\mathrm{ob}}\right)$ sebagai variabel output layer.

Kadar air awal dan akhir bahan diperoleh dengan cara mengukur kadar air pati sagu basah, dan pati sagu kering. Pengukuran dilakukan menggunakan metode gravimetri (AOAC, 2005). Sampel ditimbang sebanyak $2 \mathrm{~g}$ dalam wadah timbang $\left(W_{1}\right)$, lalu dikeringkan dalam oven pada suhu $105^{\circ} \mathrm{C}$. Sampel ditimbang setiap 2 jam selama 24 jam, hingga diperoleh berat konstan $\left(W_{2}\right)$. Pengurangan berat merupakan banyaknya air dalam sampel.

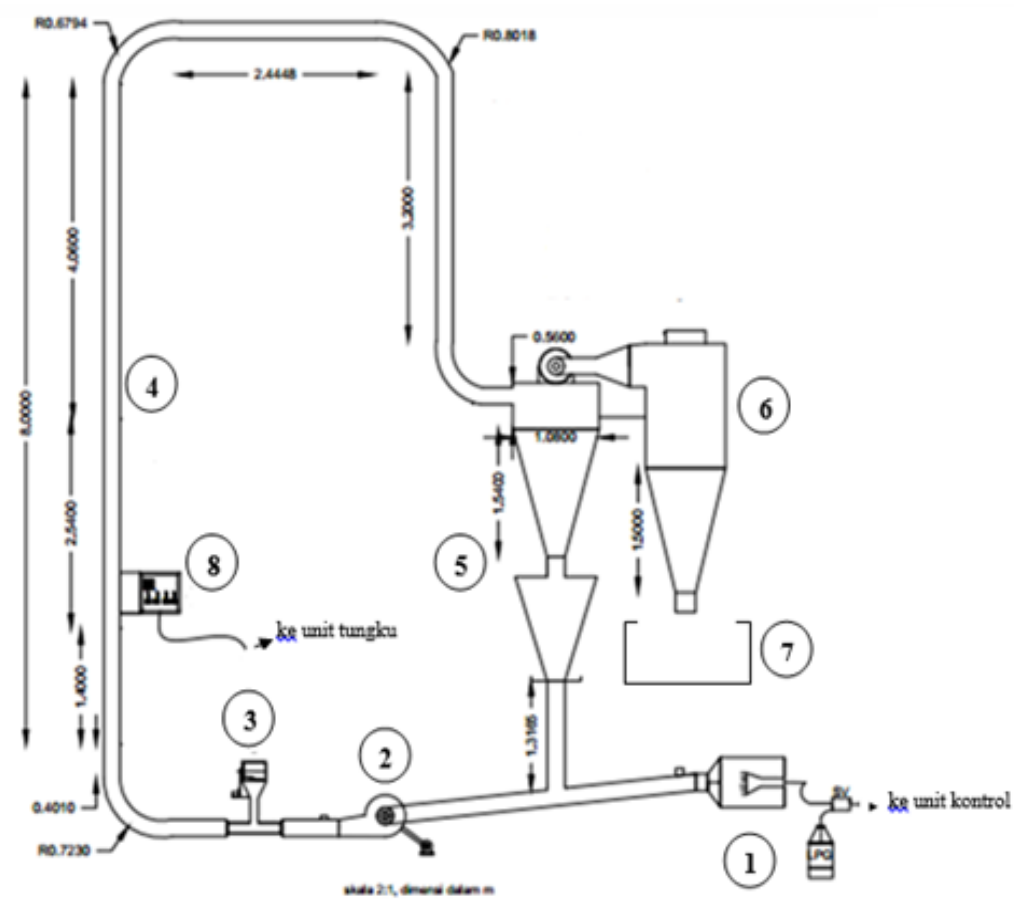

Keterangan:

(1) unit tungku dengan BBG, (2) unit blower disintegrator, (3) unit pengumpan,

(4) unit pipa pengering, (5) unit manifold atau siklon resirkulasi bahan, (6) unit siklon output bahan, (7) unit penampung bahan, (8) unit kontroller

Gambar 1. Skematis mesin PCRD 
Kadar air dihitung berdasarkan berat basah bahan menggunakan Persamaan 1.

kadar air $(\%)=\frac{W_{1}-W_{2}}{W_{1}} \times 100$

dimana $W_{1}$ adalah berat bahan basah $(\mathrm{g})$, dan $W_{2}$ adalah berat bahan kering $(\mathrm{g})$.

\section{Pemodelan Jaringan Syaraf Tiruan (JST)}

Model jaringan syaraf tiruan sangat ditentukan oleh bentuk dari struktur jaringan yang dipilih atau digunakan. Struktur jaringan berdasarkan pada inisialisasi jaringan, inisialisasi bobot, dan simulasi jaringan. Struktur jaringan yang dipilih untuk memprediksi kadar air akhir bahan $\left(\mathrm{M}_{\mathrm{ob}}\right)$ pada mesin PCRD adalah jaringan lapisan banyak (multilayer net) dengan multi input single output (MISO). Struktur jaringan JST yang digunakan terdiri dari 11 neuron input layer, hidden multilayer (tiga lapisan dengan variasi 5-5-1, 10-101, 15-15-1), dan 1 neuron output layer. Hidden multilayer dengan tiga lapisan (layer) dan tiga variasi yang digunakan dipilih secara coba-coba (trial and error) untuk mencari konfigurasi terbaik. Setiap konfigurasi jaringan dilatih sebanyak 5 kali. Hidden multilayer dengan tiga lapisan (layer) membuat pelatihan lebih mudah. Struktur jaringan JST tersebut, dapat dilihat pada Gambar 2.

Variabel yang digunakan sebagai input layer sebanyak 9 variabel yaitu kadar air input bahan $\left(\mathrm{M}_{\mathrm{ib}}\right)$, kecepatan udara pengering $\left(\mathrm{v}_{\mathrm{u}}\right)$, dan suhu udara pengering $\left(\mathrm{T}_{\mathrm{u} 3}\right)$. Input layer berikutnya adalah panjang pipa resirkulasi $\left(\mathrm{L}_{\mathrm{p}}\right)$, tinggi silinder siklon resirkulasi $\left(\mathrm{L}_{\mathrm{scrb}}\right)$, diameter pipa outlet atas pada siklon resirkulasi $\left(\mathrm{D}_{\text {Acrb }}\right)$, dan panjang pipa outlet atas pada siklon resirkulasi ( $\left.\mathrm{L}_{\mathrm{Acrb}}\right)$. Input layer selanjutnya adalah kecepatan udara blower pada siklon resirkulasi bahan ( $\left.\mathrm{v}_{\mathrm{ucrb}}\right)$, kapasitas input bahan $\left(\mathrm{Q}_{\mathrm{ib}}\right)$, kelembahan udara relatif $(\mathrm{RH})$, dan suhu lingkungan $\left(\mathrm{T}_{\text {ling }}\right)$. Variabel output layer adalah kadar air akhir bahan $\left(\mathrm{M}_{\mathrm{ob}}\right)$. Adapun variabel input layer dan nilai variasi setiap variabel dapat dilihat pada Tabel 1 .

Tabel 1. Variabel input layer untuk memprediksi $\mathrm{M}_{\mathrm{ob}}$

\begin{tabular}{ccc}
\hline Variabel & Satuan & Nilai \\
\hline $\mathrm{M}_{\mathrm{ib}}$ & $\% \mathrm{bb}$ & $21,31,41$ \\
$\mathrm{v}_{\mathrm{u}}$ & $\mathrm{m} / \mathrm{s}$ & $15,28,31$ \\
$\mathrm{~T}_{\mathrm{u} 3}$ & ${ }^{\circ} \mathrm{C}$ & $75,100,125$ \\
$\mathrm{~L}_{\mathrm{p}}$ & $\mathrm{m}$ & $9,38,11,38,13,38$ \\
$\mathrm{~L}_{\mathrm{scrb}}$ & $\mathrm{m}$ & $0,27,0,54,0,81$ \\
$\mathrm{D}_{\text {Acrb }}$ & $\mathrm{m}$ & $0,1016,0,17,0,22$ \\
$\mathrm{~L}_{\text {Acrb }}$ & $\mathrm{m}$ & $0,2,0,37,0,65$ \\
$\mathrm{~V}_{\mathrm{ucrb}}$ & $\mathrm{m} / \mathrm{s}$ & $10,75,12,75,15,75$ \\
$\mathrm{Q}_{\mathrm{ib}}$ & $\mathrm{kg} / \mathrm{s}$ & $0,00208,0,00278$, \\
& & 0,00417 \\
$\mathrm{RH}$ & $\%$ & 70 \\
$\mathrm{~T}_{\text {ling }}$ & ${ }^{\circ} \mathrm{C}$ & 32 \\
\hline
\end{tabular}

Struktur jaringan model JST yang telah terbentuk diuji dan dilatih menggunakan data observasi dengan aplikasi GUI JST berbasis Neural Network Toolbox MATLAB Versi 2014a. Menurut Kaveh dan Chayjan (2014) untuk mengembangkan model JST secara statistik, maka jaringan dilatih (trained) dalam beberapa waktu dan merekam atau menyimpan nilai terbaik pada setiap parameter. Selanjutnya model yang telah dilatih, kemudian diuji menggunakan data observasi. Data yang digunakan untuk pelatihan dan pengujian model pada penelitian ini sebanyak 81 buah set data. Data tersebut dibagi menjadi dua bagian masing-masing 54 buah set data pelatihan dan 27 buah set data pengujian model JST.

Pemisahan data pelatihan dan pengujian berdasarkan metode yang digunakan oleh Shrivastav dan Kumbhar (2009). Pemisahan data untuk pelatihan sekitar $60-70 \%$ dari jumlah data keseluruhan dan data untuk pengujian sekitar 30$40 \%$ dari jumlah data keseluruhan. Data untuk pelatihan diperoleh dari 9 variabel variasi perlakuan untuk mengetahui perubahan nilai $\mathrm{M}_{\mathrm{ob}}$ pada mesin PCRD. Setiap variabel dilakukan 3 kali variasi dan 2 kali ulangan. Data untuk pengujian diperoleh dari 9 variabel perlakuan. Setiap variabel dilakukan 3 kali variasi dan 1 kali ulangan. Variabel variasi tersebut dijadikan sebagai variabel input layer pada model JST.

Struktur jaringan yang optimal dapat tercapai apabila menggunakan fungsi transfer atau aktivasi. Fungsi aktivasi yang digunakan harus memenuhi syarat yaitu, kontinyu, terdeferensial dengan mudah dan merupakan fungsi yang tidak turun. Fungsi aktivasi logsig atau sigmoid biner memenuhi syarat tersebut. Sigmoid biner adalah fungsi transfer yang membawa input ke output dengan perhitungan logsigmoid. Nilai outputnya antara 0 hingga $1(0,1)$. Nilai fungsi aktivasi sigmoid biner dapat dihitung menggunakan Persamaan 2 (Hermawan, 2006).

$f\left(X_{j}\right)=\frac{1}{1+\exp \left(-X_{j}\right)}$

dengan turunan

$f^{\prime}\left(X_{j}\right)=f\left(X_{j}\right)\left(1-f\left(X_{j}\right)\right)$

dimana $f\left(X_{j}\right)$ adalah nilai aktivasi pada unit pengolah $j$, dan $X_{j}$ adalah nilai penjumlahan berbobot.

Algoritma pelatihan mempunyai aturan sangat penting dalam mengatur bobot-bobot (weight) dan bias-bias (biases) jaringan untuk mengurangi error antara target jaringan prediksi ( $\mathrm{M}_{\mathrm{ob}}$ prediksi) dengan data observasi ( $\mathrm{M}_{\mathrm{ob}}$ observasi). Proses pelatihan model JST menggunakan algoritma pembelajaran atau pelatihan (training algoritma). Algoritma pembelajaran yang digunakan pada penelitian ini adalah perambatan galat mundur (backpropagation). 
Input layer Hidden layer-1 Hidden layer-2 Hidden layer-3 output layer

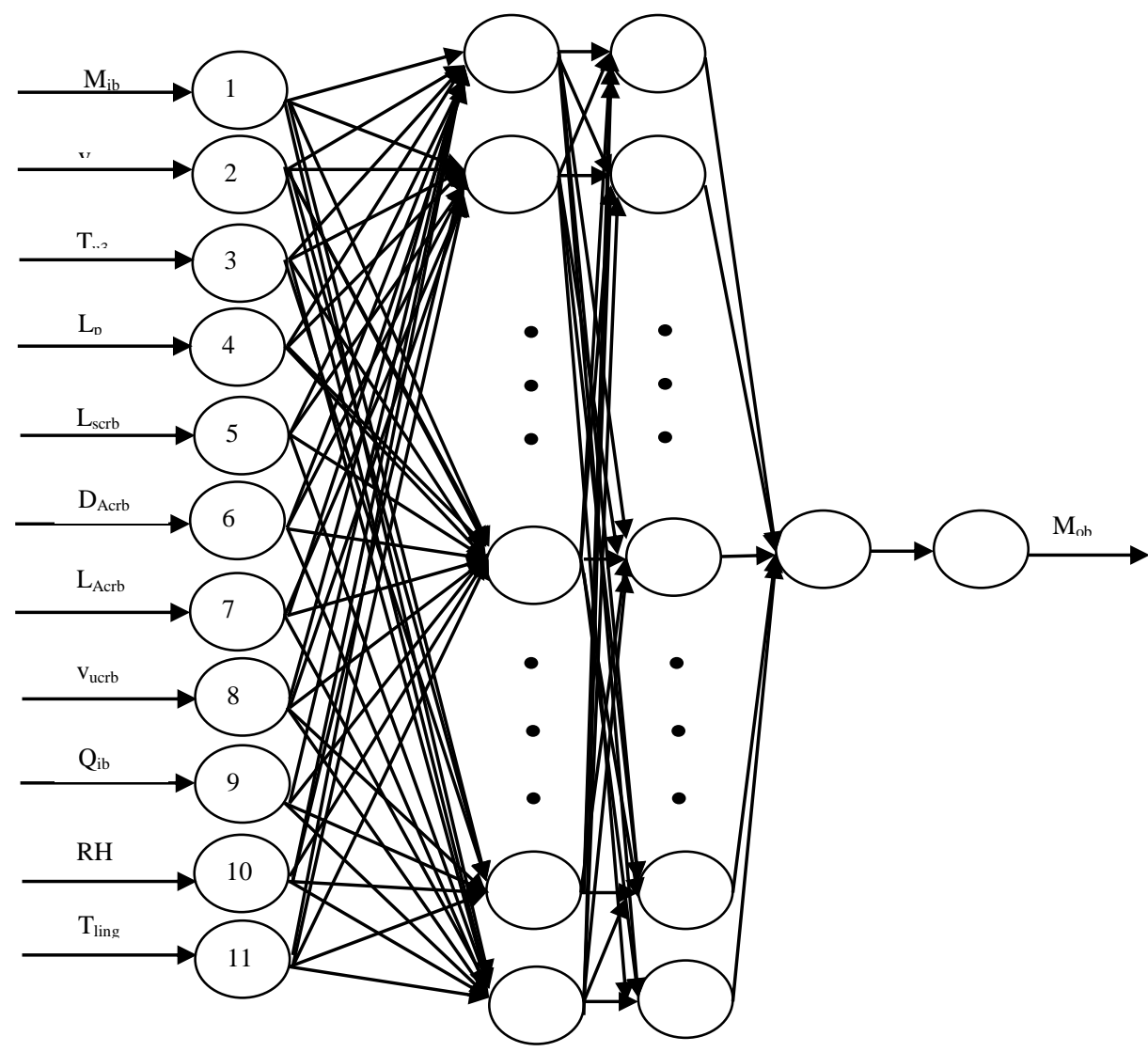

Gambar 2. Struktur jaringan model JST untuk prediksi $\mathrm{M}_{\mathrm{ob}}$

Backpropagation melatih jaringan untuk mendapatkan keseimbangan antara kemampuan jaringan mengenali pola yang digunakan selama pelatihan. Selain itu, kemampuan jaringan untuk memberikan respon yang benar terhadap pola masukan yang serupa dengan pola yang dipakai selama pelatihan (Siang, 2005). Menurut Hermawan (2006) backpropagation merupakan salah satu algoritma yang sering digunakan dalam menyelesaikan masalah-masalah yang rumit. Selanjutnya Siang (2005) mengungkapkan bahwa backpropagation yang sudah dilatih dengan baik, akan memberikan keluaran yang masuk akal jika diberikan masukan yang serupa dengan pola yang dipakai dalam pelatihan. Sedangkan bobot-bobot dan bias-bias (weights and biases) diinisialiasi secara acak kemudian diatur dengan Levenberg-Marquardt.

Levenberg-Marquardt adalah salah satu prosedur optimisasi yang digunakan pada neural network Toolbox dalam software MATLAB. Levenberg-Marquardt efektif dan cepat mencapai konvergensi. Selain itu, Levenberg-Marquardt merupakan metode non linier yang digunakan pada saat koreksi error backpropagation untuk menemukan bobot yang disesuaikan. Algoritma pembelajaran digunakan untuk mengurangi error antara target atau data prediksi dengan observasi.
Nilai error tersebut dihitung berdasarkan mean square error (MSE) menggunakan Persamaan 4.

$M S E=\frac{\sum_{i=1}^{N}\left|M_{o b-\text { prediksi, } i}-M_{o b-o b s e r v a s i, i}\right|^{2}}{N}$

dimana $M_{o b}$ adalah kadar air akhir bahan, dan $N$ adalah jumlah data yang digunakan untuk pelatihan dan pengujian model.

\section{Optimasi Model Jaringan Syaraf Tiruan (JST)}

Metode optimasi yang digunakan untuk mengetahui konfigurasi jaringan model JST yang paling optimal dari proses pelatihan dan pengujian model JST terhadap setiap variabel variasi input layer dipilih berdasarkan performance prediksi minimum error (Shrivastav dan Kumbar, 2009). Model jaringan syaraf tiruan (JST) yang optimal dapat ditentukan berdasarkan nilai root mean absolute error (RMSE), mean relative error (MRE), dan mean absolute error (MAE) (Poonnoy et al., 2007; Kaveh dan Chayjan, 2014; Chayjan et al., 2014). Nilai-nilai tersebut digunakan untuk mengetahui nilai performance dari model JST yang telah dirancang. Untuk menentukan nilai-nilai tersebut, dapat dihitung menggunakan Persamaan 5 sampai 7 (Poonnoy et al., 2007). 
$R M S E=\left[\frac{\sum_{i=1}^{N}\left|M_{o b-\text { prediksi,i }}-M_{\text {ob-observasi }}\right|^{2}}{N}\right]^{0,5} \ldots \ldots$

$M R E=\frac{\sum_{i=1}^{N}\left|\frac{M_{o b-p r e d i k s i, i}-M_{o b-o b s e r v a s i, i}}{M_{o b-o b s e r v a s i, i}}\right|}{N} \times 100$

$M A E=\frac{\sum_{i=1}^{N}\left|M_{o b-\text { prediksi, } i}-M_{o b-o b s e r v a s i, i}\right|}{N}$

dimana $M_{o b}$ adalah kadar air akhir bahan, dan $N$ adalah jumlah data yang digunakan untuk pelatihan dan pengujian model JST.

\section{HASIL DAN PEMBAHASAN}

\section{Pelatihan Model Jaringan Syaraf Tiruan (JST)}

Hasil pelatihan struktur jaringan model JST dengan 3 variasi topology pada hidden layer dapat dilihat pada Tabel 2. Variasi topology hidden layer tersebut adalah 11-5-5-1-1 (11 neuron input, 5 neuron hidden layer 1, 5 neuron hidden layer 2, 1 neuron hidden layer 3, 1 neuron output), 11-10-101-1 (11 neuron input, 10 neuron hidden layer 1,10 neuron hidden layer 2, 1 neuron hidden layer 3, 1 neuron output), dan 11-15-15-1-1 (11 neuron input, 15 neuron hidden layer 1, 15 neuron hidden layer 2 , 1 neuron hidden layer 3, 1 neuron output).

Data pada Tabel 2 menunjukkan nilai mean square error (MSE) dan nilai regresi $\left(\mathrm{r}^{2}\right.$ simulasi) yang sama dari ketiga topology hidden layer yang berbeda. Nilai MSE tersebut, digunakan sebagai dasar untuk mencapai konvergensi. Nilai MSE pada masing-masing topology hidden layer tersebut diperoleh setelah proses iterasi sebanyak 102, 143, dan 46 kali. Ketiga perlakuan tersebut menunjukan bahwa topology hidden layer yang paling baik adalah 11-15-15-1-1, sebab proses iterasinya lebih cepat untuk mencapai nilai MRE dan $r^{2}$ simulasi. Menurut Poonnoy et al. (2007) nilai MSE digunakan untuk menilai indeks performance dari suatu jaringan selama proses pelatihan. Hasil pelatihan pada masing-masing topology hidden layer dapat dilihat pada Gambar 3 sampai 5.

Hasil pelatihan jaringan model JST dengan topology hidden layer 11-5-5-1-1, dapat dilihat pada Gambar 3. Gambar 3 menunjukkan struktur jaringan, algoritma pembelajaran, progress dan plot proses pelatihan model JST. Untuk mencapai konvergen pada proses pelatihan model JST, maka diperlukan proses iterasi (epoch) sebanyak 102 kali selama 1 detik dengan nilai gradient sebesar 0,000000099,

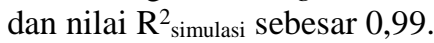

Hasil pelatihan jaringan model JST dengan topology hidden layer 11-10-10-1-1 dapat dilihat pada Gambar 4. Gambar 4 menunjukkan struktur jaringan, algoritma pembelajaran, progress dan plot, nilai gradient, dan $\mathrm{r}^{2}$ simulasi proses pelatihan model JST. Untuk mencapai konvergen, maka diperlukan proses iterasi sebanyak 143 kali selama 5 detik, dengan nilai gradient sebesar 0,000000099, dan $\mathrm{R}^{2}$ simulasi sebesar 0,99 .

Gambar 5 menunjukkan struktur jaringan, algoritma pembelajaran, progress dan plot, nilai gradient, dan nilai $\mathrm{R}^{2}$ simulasi hasil pelatihan jaringan model JST dengan topology hidden layer 11-15-151-1. Untuk mencapai konvergen, maka diperlukan proses iterasi sebanyak 46 kali selama 1 detik, dengan nilai gradient sebesar 0,000000099, dan $\mathrm{r}^{2}$ simulasi sebesar 0,99 .

Tabel 2. Nilai MSE dan $\mathrm{R}_{\text {simulasi }}$ dengan variasi topology hidden layer pada model JST

\begin{tabular}{lccc}
\hline \multirow{2}{*}{ Parameter-parameter } & \multicolumn{3}{c}{ Topology hidden layer } \\
\cline { 2 - 4 } & $\mathbf{1 1 - 5 - 5 - 1 - 1}$ & $\mathbf{1 1 - 1 0 - 1 0 - 1 - 1}$ & $\mathbf{1 1 - 1 5 - 1 5 - 1 - 1}$ \\
\hline Jumlah neuron input & 11 & 11 & 11 \\
Jumlah neuron output & 1 & 1 & 1 \\
Jumlah data untuk pelatihan & 54 & 54 & 54 \\
Jumlah data untuk pengujian & 27 & 27 & 27 \\
Jumlah neuron dalam hidden layer & $5-5-1$ & $10-10-1$ & $15-15-1$ \\
Transfer fungsi dalam hidden layer & logsigmoid & Logsigmoid & logsigmoid \\
Transfer fungsi dalam output layer & logsigmoid & Logsigmoid & logsigmoid \\
Learning rate & 0,001 & 0,001 & 0,001 \\
Momentum & $9,99 \mathrm{e}^{-08}$ & $9,99 \mathrm{e}^{-08}$ & $9,99 \mathrm{e}^{-08}$ \\
Algoritma pelatihan jaringan & Levenberg- & Levenberg- & Levenberg- \\
& Marquadrant & Marquadrant & Marquadrant \\
Jumlah iterasi (epoch) & 102 & 143 & 46 \\
Mean square error pelatihan & 0,000115 & 0,000115 & 0,000115 \\
$\mathrm{R}^{2}$ simulasi & 0,99435 & 0,99435 & 0,99435 \\
\hline
\end{tabular}




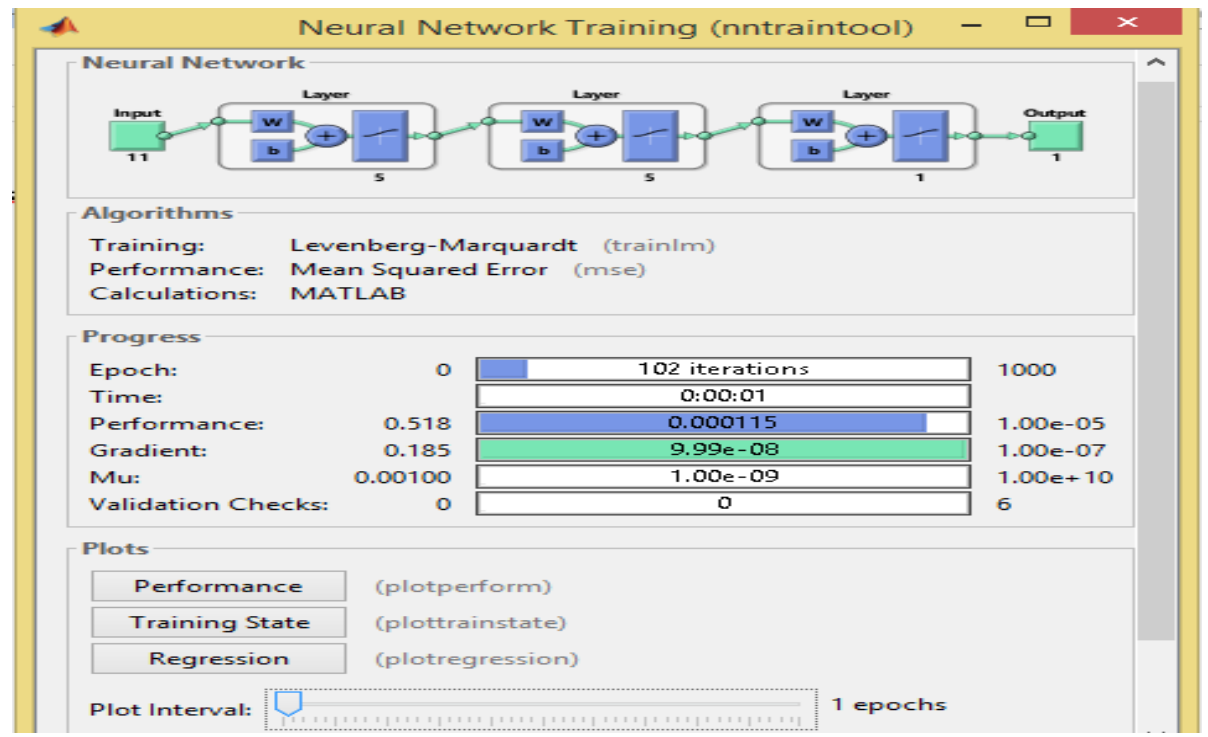

Gambar 3. Hasil pelatihan model JST dengan topology hidden layer 11-5-5-1-1

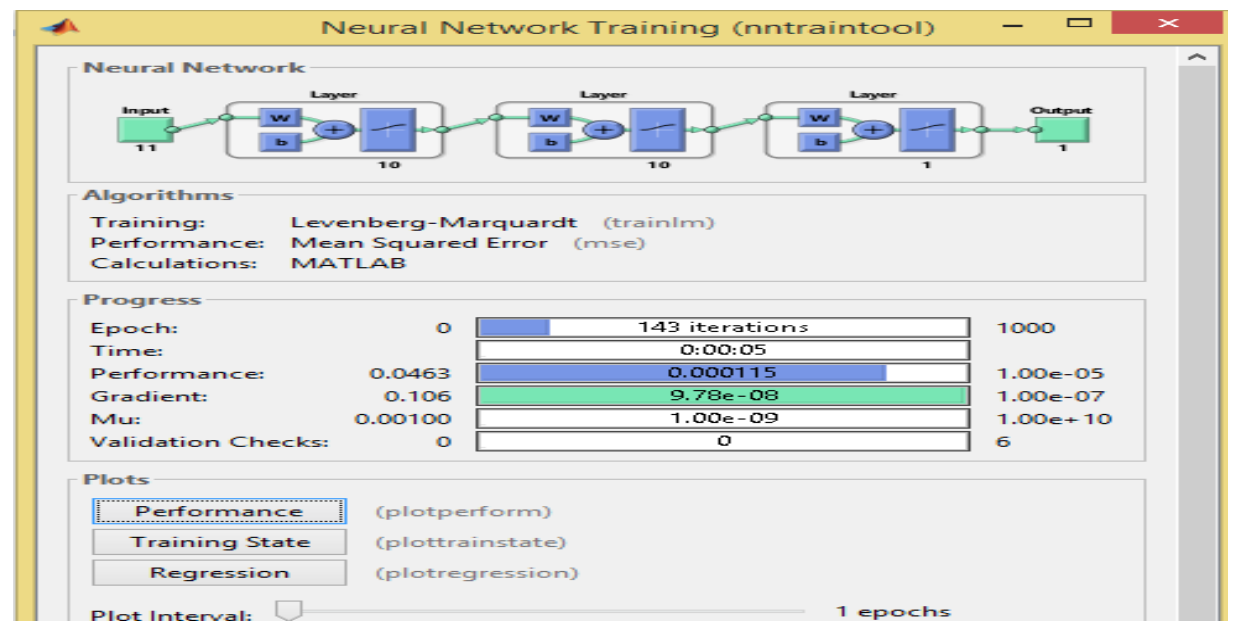

Gambar 4. Hasil pelatihan model JST dengan topology hidden layer 11-10-10-1-1

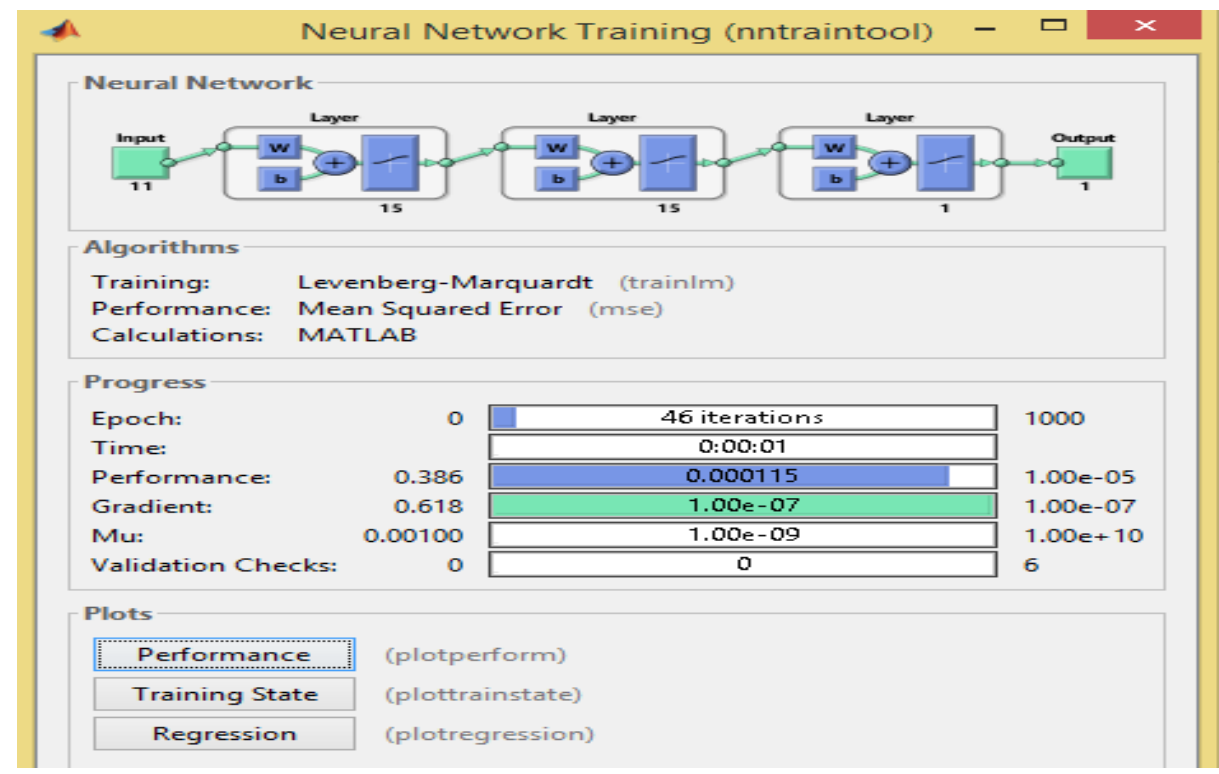

Gambar 5. Hasil pelatihan model JST dengan topology hidden layer 11-15-15-1-1: 


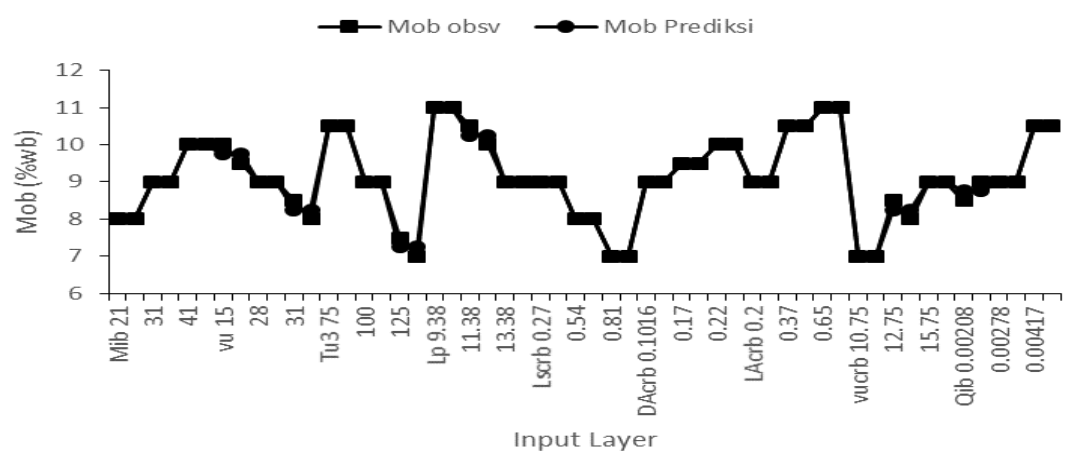

Gambar 6. Hasil pelatihan model JST pada setiap input layer

Gambar 6 menunjukkan grafik hubungan $\mathrm{M}_{\mathrm{ob}}$ observasi dan $\mathrm{M}_{\mathrm{ob}}$ prediksi hasil pelatihan model JST pada setiap input layer menggunakan aplikasi GUI JST. Grafik $\mathrm{M}_{\mathrm{ob}}$ prediksi dengan $\mathrm{M}_{\mathrm{ob}}$ observasi memiliki kecenderungan pola yang sama dan berhimpitan pada setiap variabel variasi input layer. Hal ini menunjukkan bahwa nilai error yang dihasilkan model JST tersebut sangat kecil.

Untuk menentukan nilai validitas dari hasil pelatihan dan pengujian model JST tersebut, maka dilakukan perbandingan antara kadar air akhir bahan $\left(\mathrm{M}_{\mathrm{ob}}\right)$ prediksi dengan kadar air akhir bahan observasi menggunakan analisis regresi. Persamaan regresi yang diperoleh pada proses pelatihan model JST adalah $\mathrm{M}_{\mathrm{ob}-\text { pred }}=0,989 \mathrm{M}_{\mathrm{ob} \text {-obs }}+0,103$, dengan nilai koefisien determinasi $\left(\mathrm{R}^{2}\right)$ sebesar 0,989 . Nilai 0,103 merupakan konstanta yang menunjukkan bahwa jika tidak ada penambahan $\mathrm{M}_{\mathrm{ob}}$ observasi, maka $\mathrm{M}_{\mathrm{ob}}$ prediksi naik sebesar $0,103 \%$ wb. Nilai 0,989 merupakan koefisien regresi yang menunjukkan bahwa untuk setiap penambahan $\mathrm{M}_{\mathrm{ob}}$ observasi, maka $\mathrm{M}_{\mathrm{ob}}$ prediksi naik sebesar 0,989\% wb.

Grafik hasil analisis regresi, hubungan antara $\mathbf{M}_{\mathrm{ob}}$ prediksi dengan $\mathrm{M}_{\mathrm{ob}}$ observasi hasil pelatihan model JST, dapat dilihat pada Gambar 7 . Grafik tersebut menunjukkan bahwa hubungan kadar air akhir prediksi dengan kadar air akhir observasi pada proses pelatihan model JST valid dan sahih karena nilai koefisien determinasi $\left(\mathrm{R}^{2}{ }_{\text {latih }}\right)$ yang diperoleh mendekati 1 (satu) yaitu 0,98 atau $98 \%$.

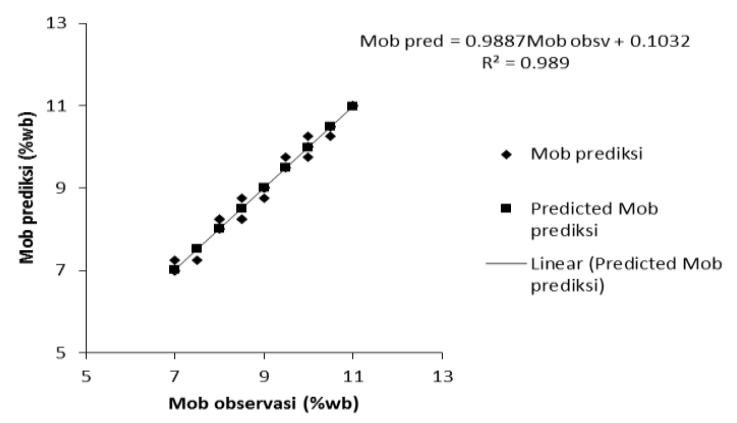

Gambar 7. Perbandingan $\mathrm{M}_{\mathrm{ob}}$ prediksi dengan $\mathrm{M}_{\mathrm{ob}}$ observasi hasil pelatihan model JST

\section{Pengujian Model Jaringan Syaraf Tiruan (JST)}

Model JST yang telah dilatih, kemudian diuji menggunakan data observasi kadar air akhir bahan yang berbeda. Pengujian dilakukan untuk mengetahui kemampuan model JST yang telah terlatih tersebut, untuk membaca data dalam memprediksi kadar air akhir bahan atau target model JST. Keakuratan model dalam memprediksi data yang diujikan ditandai dengan nilai error yang dihasilkan. Gambar 8 menunjukkan grafik hubungan $\mathrm{M}_{\mathrm{ob}}$ prediksi dan $\mathrm{M}_{\mathrm{ob}}$ observasi hasil pengujian model JST pada setiap variabel variasi inlet layer menggunakan aplikasi GUI JST. Grafik tersebut memiliki kecenderungan pola yang sama dengan grafik pada hasil pelatihan. Grafik $\mathrm{M}_{\mathrm{ob}}$ prediksi dengan $\mathbf{M}_{\mathrm{ob}}$ observasi pada setiap variabel variasi input layer juga memiliki kecenderungan pola yang sama dan berhimpitan. Namun demikian, pada parameter kadar air awal bahan $\left(\mathrm{M}_{\mathrm{ib}}\right)$, apabila dibandingkan dengan grafik hasil pelatihan terjadi pola yang berbeda, hal ini mengakibatkan nilai eror yang sangat besar pada parameter $\mathrm{M}_{\mathrm{ib}}$ dengan nilai MRE 3,715\% atau hampir mendekati $5 \%$.

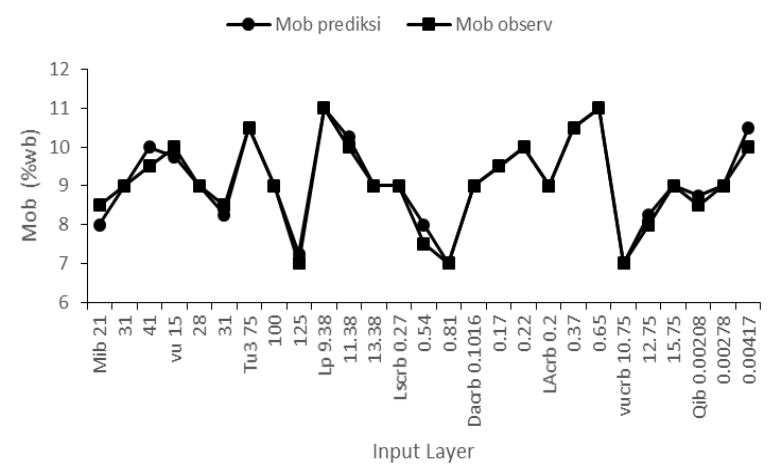

Gambar 8. Hasil pengujian model JST pada setiap input layer

Persamaan regresi dari perbandingan antara $\mathrm{M}_{\mathrm{ob}}$ prediksi dengan $\mathrm{M}_{\mathrm{ob}}$ observasi hasil pengujian model JST adalah $\mathrm{M}_{\mathrm{ob} \text {-pred }}=0,981 \mathrm{M}_{\mathrm{ob} \text {-obs }}+0,225$, dengan nilai koefisien determinasi $\left(\mathrm{r}^{2}\right)$ sebesar 0,96 . Nilai 0,225 merupakan konstanta yang menunjukkan 
bahwa jika tidak ada penambahan $\mathrm{M}_{\mathrm{ob}}$ observasi, maka $\mathrm{M}_{\mathrm{ob}}$ prediksi naik sebesar $0,225 \%$ wb. Sedangkan nilai 0,981 merupakan koefisien regresi yang menunjukkan bahwa untuk setiap penambahan $\mathrm{M}_{\mathrm{ob}}$ observasi, maka $\mathrm{M}_{\mathrm{ob}}$ prediksi naik sebesar $0,981 \%$ wb.

Grafik hasil analisis regresi hubungan antara $\mathrm{M}_{\mathrm{ob}}$ prediksi dengan $\mathrm{M}_{\mathrm{ob}}$ observasi hasil pengujian model JST, dapat dilihat pada Gambar 9. Grafik tersebut menunjukkan bahwa hubungan kadar air akhir bahan prediksi dengan kadar air akhir bahan observasi pada proses pengujian model JST adalah valid dan sahih. Hal ini karena nilai koefisien determinasi $\left(\mathrm{r}^{2} \mathrm{uji}\right)$ yang diperoleh mendekati 1 (satu), yaitu 0,961 atau $96,1 \%$. Nilai koefisien determinasi antara hasil pelatihan dengan hasil pengujian model JST tersebut hampir sama yaitu 0,989 dan 0,961 (98,9 dan 96,1\%). Menurut Shrivastav dan Kumbar (2009) model JST dengan nilai $\mathrm{r}^{2}$ yang mendekati 1 (satu), dianggap sukses digunakan dalam model prediksi. Hal ini menunjukkan bahwa model JST yang dihasilkan pada penelitian ini, valid digunakan untuk memprediksi perubahan kadar air akhir bahan dalam proses pengeringan bahan pada mesin PCRD.

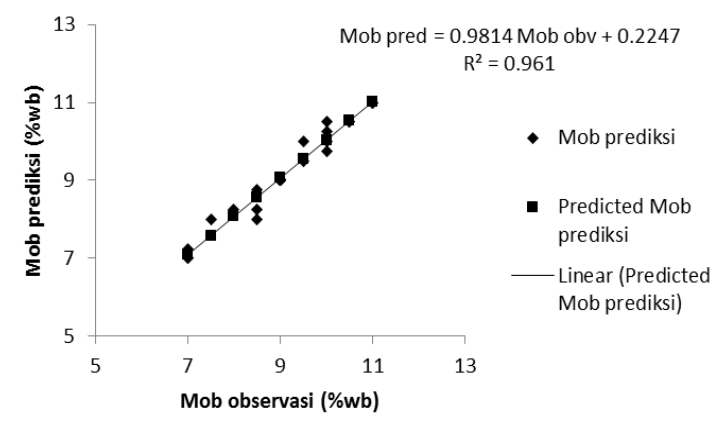

Gambar 9. Perbandingan $\mathrm{M}_{\mathrm{ob}}$ prediksi dengan $\mathrm{M}_{\mathrm{ob}}$ observasi hasil pengujian model JST

\section{Optimasi Model Jaringan Syaraf Tiruan (JST)}

Model JST yang dihasilkan, kemudian diuji tingkat optimasinya berdasarkan nilai error relatif dan absolut. Nilai error menentukan tingkat optimasi model JST sesuai target atau prediksi yang diinginkan. Semakin kecil nilai error yang dihasilkan oleh model JST, maka semakin baik struktur jaringan yang digunakan dalam memprediksi nilai target atau prediksi pada model
JST. Hasil optimasi model JST pada penelitian ini, dapat dilihat pada Tabel 3.

Data pada Tabel 3 menunjukkan bahwa variasi topology hidden layer pada proses pelatihan dan pengujian jaringan model JST, tidak mempengaruhi nilai RMSE, MAE, dan MRE. Nilainilai tersebut menunjukkan hasil yang sama pada setiap perlakuan variasi topology hidden layer. Nilai RMSE, MAE, dan MRE dihitung menggunakan Persamaan 5 sampai 7. Dari hasil perhitungan nilainilai tersebut, menunjukkan bahwa struktur jaringan yang digunakan pada model JST sangat baik untuk memprediksi kadar air akhir bahan pada mesin PCRD.

Chayjan et al. (2014) menyatakan bahwa suatu model JST yang baik, apabila menghasilkan nilai koefisien determinasi yang tinggi, sedangkan nilai RMS yang rendah. Untuk melihat pengaruh setiap variabel variasi input layer, maka dilakukan analisis optimasi dengan menghitung nilai MAE dan MRE menggunakan Persamaan 5 dan 7. Nilai MAE dan MRE pada setiap variabel variasi input layer, dapat dilihat pada Tabel 4.

\section{KESIMPULAN DAN SARAN}

\section{Kesimpulan}

Struktur jaringan model JST terbaik yang dihasilkan pada penelitian ini adalah, 11 neuron input, 15 neuron hidden layer 1, 15 neuron hidden layer 2, 1 neuron hidden layer 3, dan 1 neuron output (11-15-15-1-1) dengan algoritma pembelajaran backpropagation. Hasil uji validitas dari pelatihan model JST, diperoleh nilai $\mathrm{R}^{2}$ latih sebesar 0,98 atau 98\%, dan hasil uji validitas dari pengujian model JST diperoleh nilai $\mathrm{R}^{2}{ }_{\mathrm{uji}}$ sebesar 0,96 atau $96 \%$. Hal ini menunjukkan bahwa model valid digunakan untuk memprediksi kadar air akhir bahan dalam proses pengeringan pada mesin PCRD. Nilai optimasi model JST pada proses pelatihan diperoleh nilai RMSE sebesar $0,118 \%$ wb, MAE $0,056 \%$ wb dan MRE 0,644\%. Nilai optimasi model JST pada proses pengujian diperoleh nilai RMSE sebesar 0,226\% wb, MAE 0,129\% wb, dan MRE $1,496 \%$. Variabel yang berpengaruh adalah diameter pipa $\left(\mathrm{D}_{\mathrm{Acrb}}\right)$ dan panjang pipa $\left(\mathrm{L}_{\mathrm{Acrb}}\right)$ outlet atas pada siklon resirkulasi terhadap kadar air akhir bahan pada mesin PCRD.

Tabel 3. Optimasi model JST berdasarkan variasi hidden layer

\begin{tabular}{lcccc}
\hline & Variasi topology hidden layer & RMSE (\% wb) & MAE (\%wb) & MRE (\%) \\
\hline Pelatihan & $11-5-5-1-1$ & 0,118 & 0,056 & 0,644 \\
& $11-10-10-1-1$ & 0,118 & 0,056 & 0,644 \\
& $11-15-15-1-1$ & 0,118 & 0,056 & 0,644 \\
\hline Pengujian & $11-5-5-1-1$ & 0,226 & 0,129 & 1,496 \\
& $11-10-10-1-1$ & 0,226 & 0,129 & 1,496 \\
& $11-15-15-1-1$ & 0,226 & 0,129 & 1,496 \\
\hline
\end{tabular}


Tabel 4. Optimasi model JST pada setiap variabel variasi input layer

\begin{tabular}{lrrr}
\hline & Variabel variasi & MAE (\% wb) & MRE (\%) \\
\hline Pelatihan & $\mathrm{M}_{\mathrm{ib}}$ & 0,000001 & 0,00001 \\
$\mathrm{v}_{\mathrm{u}}$ & 0,167 & 1,866 \\
$\mathrm{~T}_{\mathrm{u} 3}$ & 0,083 & 1,151 \\
& $\mathrm{~L}_{\mathrm{p}}$ & 0,084 & 0,816 \\
$\mathrm{~L}_{\mathrm{scrb}}$ & 0,000002 & 0,000023 \\
$\mathrm{D}_{\mathrm{Acrb}}$ & 0,0000006 & 0,000006 \\
$\mathrm{~L}_{\mathrm{Acrb}}$ & 0,00002 & 0,0002 \\
& $\mathrm{~V}_{\mathrm{ucrb}}$ & 0,083 & 1,011 \\
& $\mathrm{Q}_{\mathrm{ib}}$ & 0,083 & 0,953 \\
\hline Pengujian & $\mathrm{M}_{\mathrm{ib}}$ & 0,333 & 3,715 \\
& $\mathrm{v}_{\mathrm{u}}$ & 0,167 & 1,814 \\
& $\mathrm{~T}_{\mathrm{u} 3}$ & 0,083 & 1,190 \\
& $\mathrm{~L}_{\mathrm{p}}$ & 0,084 & 0,835 \\
& $\mathrm{~L}_{\mathrm{scrb}}$ & 0,167 & 2,222 \\
$\mathrm{D}_{\mathrm{Acrb}}$ & 0,0000007 & 0,000007 \\
$\mathrm{~L}_{\mathrm{Acrb}}$ & 0,00001 & 0,00016 \\
& $\mathrm{v}_{\mathrm{ucrb}}$ & 0,083 & 1,042 \\
$\mathrm{Q}_{\mathrm{ib}}$ & 0,250 & 2,647 \\
\hline
\end{tabular}

\section{Saran}

Model JST yang dihasilkan pada penelitian ini, perlu dikembangkan dengan melakukan variasi fungsi aktivasi dan tipe pelatihan yang berbeda, sehingga model ini benar-benar dapat diterapkan untuk memprediksi kadar air akhir bahan selama proses pengeringan pada mesin PCRD.

\section{UCAPAN TERIMA KASIH}

Penulis mengucapkan terima kasih kepada semua pihak yang telah membantu selama pelaksanaan penelitian ini, lebih khusus kepada Staf teknisi laboratorium EMP dan TPP Departemen Teknik Pertanian dan Biosistem UGM, asisten lapangan dan pengembangan aplikasi GUI JST.

\section{DAFTAR PUSTAKA}

AOAC (Association of Offcial Agricultural Chemists). 2005. Official Methods of Analysis of AOAC International. Arlington Virginia. USA.

Boeri CN, da Silva FJN, dan Ferreira JAF. 2011. Use of artificial neural networks for prediction of codish drying optimal paramters. GJP\&A Sc and Tech. 12: 1-14.

Chayjan RA, Kaveh M, dan Khayati S. 2014. Modeling some drying characteristics of sour cherry (Prunus cerasus L.) under infrared radiation using mathematical models and artificial neural networks. Agricultural Engineering International Journal. 16(1): 265-279.

Christiansen OB dan Sardo MS. 2001. Find the optimum flash dryer to remove surface moisture. Chemical Engineering Progress: 54-58.
Frosterud D, Wahlberg M, Sloth J, Themens M. 2011. Selected drying technologies and particle engineering for the future biorefenery. Proceedings NWBC. Stockholm. 22-24 Maret 2011.

Hermawan A. 2006. Jaringan Syaraf Tiruan: Teori dan Aplikasi. Andi. Yogyakarta.

Kassem AES, Al-Sulaiman MA, Aboukarima AEM., Kassem SS. 2011. Predicting drying efficiency during solar drying process of grapes cluster in a box dryer using artificial neural network. Australian Journal of Basic and Applied Science. 5(6): 230-241.

Kaveh M dan Chayjan RA. 2014. Prediction of some physical and drying properties of terebinth fruit (Pistacia Atlantica L.) using artificial neural networks. Acta Pol Technol Aliment. 13(1): 65-78.

Lertworasirikul S dan Tipsuwan Y. 2007. Moisture content and water activity prediction of semi-finished cassava crackers from drying process with artificial neural network. Journal of Food Engineering. 84: 65-74.

Mittal GS dan Zhang J. 2001. Artificial neural network for the prediction of temperature, moisture and fat contents in meatballs during deep-fat frying. International Journal of Food Science and Technology. 36: 489-497.

Motevali AS, Younji RA, Chayjan N, Aghilinategh, Banakar A. 2013. Drying kinetics of dill leaves in a convective dryer. International Agrophys. 27: 39-47.

Poonnoy P, Tansakui A, dan Chinnan M. 2007. Artificial neural network modeling for temperature and moisture content prediction in tomato slices undergoing microwave-vacuum drying. Journal of Food Science. 72(1): E42-E47. 
Satish S dan Setty YP. 2005. Modeling of a continuous fluidized bed dryer using artificial neural networks. International Communications in Heat and Mass Transfer. 32: 539-547.

Shrivastav S dan Kumbhar BK. 2009. Modeling and optimization for prediction of moisture content, drying rates, and moisture ratio. International Journal Agricultural \& Biological Engineering. 2(1): 58-64.

Siang JJ. 2005. Jaringan Syaraf Tiruan dan Pemrogramannya Menggunakan Matlab. Yogyakarta: Andi Offets.
Singh NJ dan Pandey RK. 2011. Neural network approaches for prediction of drying kinetics during drying of sweet potato. Agricultural Engineering International (CIGR Journal). 13(1): 1-12.

Topuz A. 2010. Predicting moisture content of agricultural products using artificial neural networks. Advances in Engineering Software. 41: 464-470.

Torrecilla JS, Aragon JM, dan Palancar MC. 2005. Modeling the drying of a high-moisture solid with an artificial neural network. Ind. Eng. Chme. Res. 44: 8057-8066. 